\title{
Power and
}

precariousness in the expert hierarchies of the US hydrocarbon industry

Critique of Anthropology 202I, Vol. 4I(3) 303-3I9

(C) The Author(s) 2021

(c) (i)

Article reuse guidelines: sagepub.com/journals-permissions DOI: I0.1 I77/0308275X2 I I038608 journals.sagepub.com/home/coa

@SAGE

\section{Sean Field (D)}

University of St Andrews, Scotland

\begin{abstract}
Drawing on ethnographic research in Houston, Texas, I explore how oil and gas experts negotiate social power and precariousness within the US hydrocarbon sector. In an industry long associated with corporate power, the careers of experts are precariously balanced on rising and falling hydrocarbon prices. This makes the social power these experts wield as fluid as the commodities they are premised on. I show that informal social networks solidified by industry associations can buffer this precariousness by opening new employment opportunities and allowing them to maintain their connection to elite industry circles through periods of unemployment and uncertainty. For many working in the industry, precariousness defines the US hydrocarbon sector as much as the wealth that it is known to generate. Precariousness, I argue, is not just experienced by specific groups of people but rather is a general characteristic of capitalism that touches all but a select few.
\end{abstract}

\section{Keywords}

Expertise, hydrocarbons, precariousness, social networks, social power

\section{Corresponding author:}

Sean Field, Centre for Energy Ethics \& Department of Social Anthropology, University of St Andrews, St Andrews, Scotland.

Email: sf95@st-andrews.ac.uk 
I met Sam in the elevator on the way to the Petroleum Club in downtown Houston, Texas. ${ }^{1}$ He extended his arm to shake hands with me and said in a confident tone: 'Sam Wilson'. We were both on our way to a monthly luncheon hosted by the Houston Oil Association, which is attended by the hydrocarbon industry's corporate elite. Sam told me that he is a founding member of the association and a regular at 'the club'. 2 We chatted on the 35-floor ascent, as we strolled off the elevator into the Petroleum Club's ornate lobby, and down the lush-carpeted hallway to a vast reception room overlooking the cityscape. With a décor described by its interior designer as 'Madmen style', the predominantly black and gold internal colour scheme of the club is a symbolic representation of the American oil industry's mainstay commodity, crude oil, and the wealth that American oil capitalism can generate ${ }^{3}$ (McLean, 2018: 82). The Petroleum Club exemplifies the power and prestige of the US oil industry. This is where successful and aspiring 'oil men' come to dine in luxury, drink bourbon and socialize. It is the perfect location for marque industry events like this luncheon. Sam and I collected our prepared name placards at the reception desk and blended into the crowd of men wearing suits, where I spotted several interlocutors from my field work.

Sam, I later found out, has decades of experience in the Texas oil industry and has held multiple roles over his career. He has worked as a commercial lender to oil and gas companies, an investment banker with Enron, an executive of a mediumsized independent exploration and production company, and as an industry consultant. 'Have you ever been on a rig?' he asks with a grin; 'It's intoxicating ... oil gets in your blood', 'I just love the industry, and I love the people in it.' For Sam, the industry represents the best of American capitalism: it provides opportunities for aspiring oil entrepreneurs and 'wildcatters' who are willing to take personal financial risks, and it creates jobs and fuels domestic national economic growth. Working in the US oil industry is a source of personal and nationalistic pride for Sam, but you need 'to know the right people' he told me. 'As big as [the industry] is', he says, 'it's amazing ... how closed it is.' This association luncheon is part of a performance in knowing 'the right people'. The luncheons are opportunities to network with colleagues in the middle and upper expert echelons of the industry, exchange business cards with new contacts and talk about deals that are not yet public. Sam seemed to know almost everyone and introduced me to several people. Tall with hair neatly parted to the side, he confidently moved through the crowd, joining one small group of men talking and joking, then after a few minutes he joined another, and later another. He and the others shook hands, swapped stories, talked business and slapped each other on the shoulders after delivering their punchlines. It all seemed grand and Sam was one of a few people at the centre of it all. I was surprised, then, that when I called the phone number on Sam's business card few days later, the woman who answered said he was no longer with the firm and could not be reached. Sam's status in the industry's expert hierarchies was seemingly more precarious than it had first appeared.

The luncheon and my interaction with Sam reminded me of Mason's (2019) description of the performance of hydrocarbon expertise. Mason (2019) has shown 
that experts play a central role in producing and distributing technological and economic knowledge in the US hydrocarbon industry, but that the performance of expertise is not purely technical. There is also a socio-corporeal element to this performance he suggests, a 'social life of energy extraction' (Mason, 2019: 125). Luxury settings where industry events are hosted are a key aspect of this performance $^{4}$ (Mason and Stoilkova, 2012). These performances are the qualitative dimension of experts' social power that demonstrate the quality of their knowledge (Mason, 2019). Ho (2009) and Zaloom (2004) have similarly observed that embodied performances are crucial to expertise inside investment bank and derivative trading communities. For Zaloom's (2004) traders, this performance on the trading floor (before mass digitization) was an aggressive masculine physical exchange of pushing, shoving, yelling and physical positioning. For Ho (2009: 37, 41), the performance of expertise in the investment banking community was founded on the 'power' of elite 'whiteness' and the outward appearance of 'being impeccably and smartly dressed'. Yet, as Ho (2009), Miyazaki (2013) and Zaloom (2004) have demonstrated, social hierarchies of expertise can be fluid and shifting. Ho (2009: 273) explains 'layoffs and job insecurity' forms part of the cultural fabric of the New York investment banking community; job precariousness is the 'risk' associated with the financial rewards that investment banking can yield for those working in the industry (Ho, 2009: 257, 272-3). For Miyazaki (2013), the professional fate of the arbitrage unit inside the Japanese bank where his ethnography was based was determined when the bank decided to disband the unit after it had been out-competed by American and European arbitrageurs. For Zaloom (2004), several bad trades left one commodity trader literally sleeping on the street. What these scholars show is that the performance of expertise entails embodied social interactions with others, and that the employment and social status of experts can be precarious. These works, however, focus on workplace settings and working relationships within firms and workplaces. What they do not explore is how informal social networks that cut across firms and are solidified by industry associations, are an element of expert performance that can buffer social and employment precariousness and keep people within these communities through periods of unemployment.

In an industry long associated with the corporate power of oil majors, the social power of experts within the industry's hierarchies is fluid and at times tenuous waxing and waning with boom-bust cycles in hydrocarbon prices that can lead to mass layoffs and unemployment. While I explore how industry insiders ethically value hydrocarbons and how they engage with risk and responsibility elsewhere, here I advance the literature on experts by showing how informal social networks are key to the performance of expertise and, importantly, a means by which to hedge against social and employment precariousness (Field, in press, forthcoming a). Maintaining the 'economy of appearances' through informal social networks and embodied performances in elite industry spaces, I show, is vital to helping interlocutors retain some social power through bouts of unemployment by maintaining their connections within, and belonging to, the hydrocarbon industry's 
expert hierarchies (Tsing, 2000: 115). In the process, I respond to Souleles and Archer's (this issue) provocation on 'studying up' by providing novel insights into how social power and precariousness are negotiated within an industry seen by many outsiders as monolithically 'powerful' (Hughes, 2017: 4; Maddow, 2020: xx). To do this, I draw on ethnographic field research that I began in late 2018 in Houston, Texas, when the industry teetered on, then entered, a 'bust' cycle with stagnating and later falling oil prices. My interlocutors include private equity partners, managing directors, bankers, lawyers, accountants, consultants and engineers engaged in the practice of energy investing and lending (most in senior and leadership positions). They let me into their offices, their homes, and their lives, enabling me to carry out interviews, participate in private industry events, "hang out' with them informally, and observe the oil finance sector from inside the enigmatic close-knit social circles that cut across firms. I begin by discussing the entanglement of hydrocarbon expertise, social power dynamics, and precariousness, including distinguishing precariousness from precarity. I then turn attention back to Sam and other interlocutors in the industry. I reflect on what these ethnographic examples show and how precariousness (and hedging against it) is as much a part of the industry as trying to claim a piece of the wealth that hydrocarbons generate. I conclude by suggesting that, while my interlocutors are not the precariat, the distinction between precarity and precariousness is blurred, and that precariousness is perhaps a more general characteristic of capitalism.

\section{Hydrocarbon expertise, precariousness and shifting social power dynamics}

Finding hydrocarbons and controlling the mineral rights to produce them is at the heart of wildcatter dreams of becoming successful 'oil men', the source of oil family fortunes, and the profit-making aspirations of independent producers and corporate oil majors alike (Appel, 2019; Clark, 2016; High, forthcoming). Even before hydrocarbons are extracted from deep underground, however, deposits are commodified as units of oil and gas to be extracted (Field, in press; Wood, 2016). The rights to these future hydrocarbons can be bought, sold and traded for a portion of their future expected financial value based on engineering and financial experts' estimates and projections (Field, forthcoming a; Wood, 2016). Once produced, oil and gas enters a world of pipelines, pumping stations, storage tanks and refineries on the way to the point of consumption (High and Field, 2020; Simpson, 2019). From initial hydrocarbon exploration and the 'potentiality' of oil, to the marketing of refined oil and gas products, leagues of contractors and various experts are involved in the process - deriving a piece of the financial value that hydrocarbons generate in the form of compensation, fees, interest and profit sharing (Weszkalnys, 2015; Wood, 2019).

Only a handful of interlocutors I know are independent 'oil men', carving careers and identities from personally financing and directing their own 
exploration and production companies. The majority of my interlocutors are financial, legal, and technological specialists who use the power of their expertise to 'chase oil', as one interlocutor put it. In their various roles, experts play a vital part in the US oil and gas industry - making and steering managerial decisions, crafting financial imaginaries of the future, deciding whether wells are drilled, and acting as gatekeepers of capital (Field, in press; Mason, 2019). Their expertise combines experiential-performance with authoritative ways of 'knowing' (Boyer, 2008). 'Knowing' is signalled by their insider knowledge and usage of the industry's lexicon - the 'economic-oil speak', industry-specific legal terms, financial metrics, and forecast modelling (Carr, 2010; Field, forthcoming a; Mason, 2019). Experiential-performance, meanwhile, is demonstrated through their professional achievements (number of deals they have closed for example) and their socio-corporeal performances in industry spaces and at industry events.

When interlocutors in Houston talk about 'power' they often refer to the industrial-technological capacity of hydrocarbons 'to do work', and marvel at how this consolidated form of solar-biogenic energy concealed underground has yielded innumerable benefits for people around the world (Lennon, 2017: 19). These reflections often give way to how industrial-technological power is connected to social and geopolitical power. Power is used by some interlocutors in a geopolitical sense to refer to the 'market power' of OPEC countries, Russia, and China to influence the price, supply and demand for oil in competition with the United States. Many interlocutors, like Sam for example, talk about their work in the oil and gas sector as contributing to a nationalist project and the maintenance of American geopolitical supremacy. 'Cheap gasoline', Sam pridefully told me, is what keeps planes, cars and trucks moving across the United States and around the world - it is the 'lifeblood' of American capitalism (Huber, 2013). Like High's (2019) interlocutors in Colorado's hydrocarbon industry, the ethical obligation of powering American capitalism is what drew some of them to the oil industry and keeps them in it - like Sam.

In other instances, power emerges as regional and localized social 'power structures', as one interlocutor put it, grounded in oil family dynasties and personal fortunes that can impede or finance the entrepreneurial ambitions of aspiring 'oil men'. Many in the industry's expert hierarchies are well compensated, especially those at the top. On the one hand, wealth is symbolic of social significance and the cumulative importance of experts' creative labour (Graeber, 2001). As one interlocutor told me: 'making money is a way of keeping score' of how 'good' someone is. On the other hand, wealth (especially extreme forms) enables individuals' capacity for elite agential social action - it can release individuals from the necessity to work to earn money, give them the capacity to exert social influence through philanthropic activities, and endow them as aspirational symbols of prestige. It also enables them to exert control on the world around them through the purchase and ownership of assets, companies and labour. Many interlocutors that I know within the industry's expert ranks aspire to make their fortunes in oil and gas and become 'billionaires', hoping their expertise and networks that cut across social 
strata of the highest echelons and firms will facilitate this ascent. Organizations such as the Houston Oil Association and venues such as the Petroleum Club are some of the exclusive spaces where experts and social elites from across the industry can informally network.

Boyer (2014) suggests that one way to frame how social power operates in energy industries is in terms of 'energopower'. Energopower takes its cue from Foucault's biopower as a way to frame interventions of expertise and authority on issues of energy and the Anthropocene (Boyer, 2014: 322). For Boyer (2014: 325), energopower is akin to biopower but pays specific attention to how political power operates through electricity and fuel. The problem with this concept, as formulated, is that it is a 'provocative placeholder' rather than a definitive concept and leaves vague the ways that social power dynamics might unfold in energy industries via everyday practices. For Foucault, by contrast, the concept of (bio)power is 'shorthand for... relations of power' that can be structured by institutions or prevailing social norms at particular times and places. Power, in Foucault's formulation, emerges as the ability to control and influence the conduct of others; while institutions and norms can help stabilize webs of social relations into hierarchical power structures, these relationships are 'mobile... and not fixed once and for all' (Foucault, 1994: 291-2). For framing how social power dynamics unfold in the expert hierarchies of the hydrocarbon industry, this conceptualization is far more helpful. My observation is that the social power structures within the industry can be conceptualized as overlapping and semi-fluid organizational and social hierarchies where people occupy multiple shifting positions based on their professional roles, association memberships, and familial networks. Individuals' positions within these hierarchies are characterized by their agential capacity to exert influence and control over the hierarchical dynamics around them and the material economic processes in the hydrocarbon industry using their wealth and expertise. ${ }^{5}$ They are semi-fluid because, while many interlocutors I know are wealthy and powerful in their own regard, their careers and strategic positions in these hierarchies are precariously balanced on rising and falling commodity prices, intercapitalist competition and industry trends.

Precariousness has been used to describe and conceptualize the predicament of crafting livelihoods in circumstances that are, in varying degrees, out of our individual control (Butler, 2004, 2009; Mattingly, 2012). Often it has been applied to those trying to craft a livelihood from subsistence activities and "short-term "gigs", (Kasmir, 2018: 2), although it has also been more broadly deployed to describe an absence of secure employment. For Allison (2013), for example, precarity refers to a deviation from the historically specific and placed-based Fordist norm of secure work and income. Butler (2009), by contrast, distinguishes precarity from precariousness. Butler (2009) uses precarity to denote an unequally distributed corporeal vulnerability imposed on people by natural disasters, war and poverty, delineated along the lines of privilege in her analysis of war. She uses precariousness, meanwhile, to denote a collective corporeal vulnerability - a shared human condition that implies 'a dependency on people we know, or barely know, or know not at all' 
(Butler 2009: 14). Without adopting the corporeal specifics of Butler's (2009) analytical lens, this is a helpful distinction for the present analysis. Sam and other interlocutors I know are not part of an under-privileged precariat that experience precarity in the sense describe by Butler (2009), as they are often empowered in their managerial roles to implement labour regimes on workers that give rise to precarious work for others. At these upper echelons of the industry's hierarchies, one might assume that they are beyond precariousness. Yet, even at these high levels, they too are subject to social and employment instability associated with capitalism and induced by hydrocarbon price cycles, where US oil prices historically tend to crash every six to ten years. They experience precariousness. For Sam and others, precariousness forms part of their identity and a capitalistic lifestyle in ways that depart from traditional notions of precariousness that centre on poverty and a lack of structural decision-making power. For them, social and employment precariousness in the elite expert hierarchies of the hydrocarbon industry is the precondition for claiming a piece of the wealth the industry generates. It is part of the wildcatter ethos that reverberates throughout the US industry's ranks and is a fundamental characteristic of capitalism, whereby precariousness touches almost everyone.

Informal professional networks solidified by industry associations can hedge some of the social and employment precariousness of working in the industry's upper echelons. As Salverda and Abbink (2013: 12) suggest, 'ties of friendship ... clubs, hunting parties, [and] families' can 'create culturally validated bonds of trust... solidarity and commonality of interest' that are under-emphasized in analyses of formal social hierarchies set by firms and institutions (Salverda and Abbink, 2013: 12). Even Mills (1964 [1956]: 37, 39), who took formalized social hierarchies as his analytical framework, emphasized the importance of informally organized 'crowds' of the old, new and aspiring upper classes who 'know one another, see one another socially and at business'. For Mills (1964 [1956]: 11, 37), these 'crowds' have overlapping personal and professional backgrounds and 'take one another into account' in 'coordinat[ing] viewpoints and decisions' in business and society. In a similar vein, Courtois (2013: 163) found social events and exclusive clubs can solidify and prolong social connections within the business community in her exploration of elite schools and corporate executives in Ireland. Social networks help build consensus among elites, she contends, and provide a space for 'political, corporate, and social elites, old wealth and new wealth, to mingle informally' (Courtois, 2013: 163). Ho (2009) too emphasizes the importance of informal networks in her ethnography of Wall Street; for Ho (2009: 13, 86-7), kinship and elite university networks are a bridge to employment in finance. Settings such as 'bars' and 'the golf course' are as important as the boardroom in making and solidifying these social bonds (Ho, 2009: 87). Having 'strong' networks is also key to surviving bouts of unemployment for elite bankers, Ho (2009: 220) suggests, although she does not elaborate on this point. Here, I pick up where these authors leave off by drawing on several ethnographic encounters in the US hydrocarbon industry to show how informal social networks and embodied 
socio-corporeal performances in industry spaces not only advance private and corporate interests, but are key to surviving social and employment precariousness. I begin by returning to my encounter with Sam.

\section{'Mississippi riverboat gambler'}

When Sam and I parted at the luncheon, he enthusiastically agreed to meet in the coming weeks. I tried to get in touch with him in the following days, but my emails went unanswered and I could not reach him by phone. Sam unexpectedly called me on the phone a few days later. Instead of beaming with confidence, his voice now sounded strained. There were several long pauses, and his words were punctuated by a couple of elongated sighs and 'errrr's as he seemingly searched for the right words as we spoke. He told me that he had given me his 'old business card' and explained that he had recently, and abruptly, left the firm that he had been employed with - he had been let go. The last few weeks had been 'difficult', he said, but he insisted it was a 'good' move for him. He was setting up his own firm now, which was why it had taken him a while to get in touch - he had been busy getting his next project established.

We met a week later for lunch at a pub on the west side of Houston. Far from the glamour and formality of the Petroleum Club, this time Sam was wearing a golf shirt and slacks. I met him outside and we shook hands as he strolled over from his large luxury SUV. His confidence seemed renewed. Over lunch we continued our conversation from a few weeks earlier about the highs and lows of working in the oil and gas industry. Reflecting on the industry downturn and his recent change in employment, he explained:

This industry has so much cyclicality, so much up and down, and uncertainty.... I think anybody that gets in this industry and stays in it, somewhere in their bloodline... it's got to be a Mississippi riverboat gambler, because it's the only way you can stay in this industry. You've got to have somebody in your background, in your family tree, there has got to be somebody who's willing to roll the dice.

Like many interlocutors, Sam approaches his career in the oil and gas industry with a sense of optimistic fatalism. Having been in the industry for decades, he knows that long downward trends in the price of hydrocarbons mean job precariousness and perhaps unemployment, even for industry veterans like him. When oil and gas prices are going up, business can go 'really well', he says; but, when 'oil and gas prices tank' business can be 'really tough'. Working as a consultant, he relies heavily on his networks of colleagues and industry friends to generate business in 'tough' times. He looked at me and said: 'I know enough people in the industry ... to make a living based on helping to fill some of their needs.' It was through his industry social networks that he acquired the job he had just abruptly lost; he subsequently relied on these networks, perhaps more than ever, as he started his own consultancy. 
I continued to meet with Sam at the monthly industry association meetings at the Petroleum Club over the coming months. Suit-clad and proud, he continued in his role as one of the association's founding members - networking and chatting with old colleagues, association guests and new members. Sam reminded me of the multiple ways that social power and precariousness is negotiated in this community of hydrocarbon experts and 'oil men'. While disempowered by the recent change in his employment, he vied to maintain some of his social status in the community through his presence and socio-corporeal performance at the association - being seen and maintaining friendships and networks with the 'right' people in positions of social power. Sam's expertise is not just managerial advising and technical forecasting, it also draws on the economy of appearances - the dramatic performance of success and confidence even in times of personal precariousness. Sam is not unique in this regard, however. I met Shane, for example, on the way to a monthly breakfast meeting of another industry club, the Oil Finance Association, in late 2019. Its meetings are smaller than the luncheon meetings of the Houston Oil Association, and more focused on the city's oil finance sector. Hosted at a discreet downtown location not far from the Petroleum Club, key figures from across Houston's energy finance sector gather once a month to talk about finance deals, to network, and to share industry gossip. 'Going to the association breakfast?' he asked as we both strolled onto the elevator. We had seen each other before at previous meetings but had never chatted. Shane holds multiple roles in the industry - in addition to being a senior executive with a private investment firm, he consults with some of the largest oil and gas private equity firms in Houston. We shook hands and exchanged business cards, as is custom among my interlocutors, and strolled out of the elevator into the large lobby to join dozens of suit-clad men drinking coffee and chatting in small groups. As we retrieved our prepared association name tags from the reception table that identified us as members, another man joined us. Shane knew him - they shook hands and he introduced us. 'Bob's at Slate Capital ...' Shane said, as his eyes drifted towards the hand-written white paper name tag Bob had just attached to his lapel - unlike our association branded engraved name tags. 'Actually', Bob said, 'I'm on my own... I'm no longer with them.' Like Sam, Bob abruptly found himself 'selfemployed' and looking for work after decades of working in the industry. Quickly setting up one's own home-based firm for self-employment was a strategy several interlocutors I know deployed in response to sudden changes in their employment status. Shane let out a billowing laugh as he pointed to Bob's paper name tag with the name of his new company 'Bob Z's Investment Associates Inc.'. Seemingly embarrassed and uncomfortable with Shane's reaction, Bob's face looked like he had just swallowed a spider, and he shifted from one loafer to the other. Shane slapped Bob on the shoulder in an 'old pal' sort of way and told us he had to 'go talk to some people' before confidently strolling into the adjacent crowd of suits. Bob was unable to salvage the interaction and, seemingly deflated, shook hands and exchanged business cards with me before he too disappeared into the crowd, although far less boisterously than Shane. He was 
incapable of performing the economy of appearances as well as Sam in the face of precariousness - his socio-corporeal presentation was less polished and undermined the quality of his expertise via his embodied performance. This interaction is illustrative of negotiating the shifting interpersonal social-power dynamics between members of this exclusive club of energy financiers and how asymmetries can emerge as, and in, social interactions. While Bob and Shane are peers and both are members of the association, Bob's status was seemingly diminished by his sudden change in employment. He no longer had the institutional power he once held as a gatekeeper of capital; and while his expertise was not diminished, his ability to exert influence within the industry through his professional role seemingly had. This association meeting was an opportunity to maintain his connection with this elite community, even if some interactions, like the one with Shane, were humbling.

The precariousness experienced by Sam and Bob is not uncommon in expert hierarchies of the US hydrocarbon industry. The 'utterly confusing' and 'mindboggling' volatility of hydrocarbon prices can lead to thousands of layoffs, challenging the moral ambitions of those working in the industry to persevere in the face of dismal personal financial prospects (Appel et al., 2015: 8; High, 2019; Wood, 2019). Recently, an analyst with a young family that I know found the entire oil and gas unit at the investment bank he worked for in Houston laid off, including him - to his surprise. As a junior analyst without extensive social networks in the industry, it took him several months to secure a new entry-level position, which was later liquidated as the industry descended into a deep retraction. In a similar example, in the autumn of 2019, over half the staff in the oil and gas unit at Wells Fargo in Houston, which competes with JP Morgan Chase and Bank of America to be the largest commercial financier to the oil and gas industry, were liquidated to the surprise of interlocutors I know. Many I know hope oil and gas prices will rise, instigating a 'boom' in employment and compensation, with the knowledge that falling commodity prices and associated job 'purges' (as one interlocutor put it) across the sector are inevitable. My ethnographic encounters with Sam and Bob highlight some of the ways that informal social networks, solidified through industry associations, can buttress this erosion - even if only partially. Associations that connect people across firms not only symbolize who is in this community, they are also a means of showing who is still in 'the game' through boom-and-bust cycles.

\section{'I don't want to retire'}

Like Sam and Bob, Peter is well acquainted with the precariousness that working in the US hydrocarbon industry can bring. When we first met in 2019, he confided in me that he was actively searching for a new job opportunity because he was not sure how much longer his current job would last. In his current role, he is a management consultant specializing in large corporate bankruptcies and restructuring in the hydrocarbon sector. There was little bankruptcy work at the 
beginning of 2019 when we first met, and the fate of senior directors at his firm depended on quarterly reviews of how much business and profit each staff member was contributing to the firm. Peter has nearly four decades of experience, having held senior roles as an engineer, investment banker, commercial lender, and executive of an exploration and production company to name a few. He originally trained as a petroleum engineer because, he told me, it paid well and he hoped it would let him travel the world. Now, as a senior director, he is a member of a number of exclusive associations and I sometimes see him at the luncheons at the Petroleum Club - although we meet up regularly outside the club. At times in his career, Peter has found himself involuntarily unemployed. In bad times, he says, it can be hard to 'show your face' at association meetings and industry events. Maintaining social networks through industry associations and saving face through bouts of unemployment is important, but shifting social dynamics among colleagues can make for uncomfortable encounters and make one feel vulnerable - like Bob. Describing an exchange with his wife during one these periods of 'self-employment', he said:

My wife said I was unemployed. I said I'm not unemployed. I'm self-employed. You can't be unemployed when you're self-employed.... Eventually, after months of not earning any money, I had to concede I was probably unemployed.

His informal social networks eventually helped him weather this period of 'selfemployment' through private consultancy work and later an employment opportunity. With the recent downturn that has enveloped the hydrocarbon industry since late-2019, his work in bankruptcies is busy and secure for the foreseeable future. In his current counter-cyclical professional role, the expert power that Peter wields is helping corporate managers across the US oil and gas industry decide who will get paid and what will be written off. He explained,

One of the exercises in bankruptcy is deciding: This is how the company is going to come out of bankruptcy, this is how they're going to finance it, these are the wells they're going to drill.

Alternatively, he says, we 'liquidate the company ... let everybody go and sell the assets', in a conversational exchange that reminded me of Ho's (2009) ethnography of Wall Street. He told me that he gets phone calls a couple times a week from colleagues and friends across the industry who are 'nervous' about their job security or recently 'self-employed', wanting to know if his firm is hiring experienced energy financiers and senior managers. Suggesting that there is a limit to which social networks can buffer precariousness in the midst of a major downturn, Peter told me: 'It's understood by people who've been around, that this might be what pushes them out of the industry into retirement or into other [industries]...'

Sometimes he gets calls from people within the far stretches of his social network wanting his assessment of other people in the industry: Who are they? 
Are they trustworthy? Are they an 'asshole'? Informal networks within the industry not only provide new job opportunities but also a system of 'checks', Peter and others told me. With a few phone calls, a person in this community of experts can figure out who a newcomer or an insider is, who they know, and whether they should do business with them. It is, relatedly, no coincidence that the interlocutors I describe are white men not unlike myself. In one of the most racially diverse cities in the Unites States, non-white workers are estimated to comprise only $12 \%$ of the industry's work force, and African Americans only 7\% (Greater Houston Partnership, 2020; Osborne, 2020). Women account for 10-15\% of the workforce, of whom very few hold executive and managerial positions ${ }^{6}$ (Yanosek et al., 2019). As I address elsewhere, interlocutors said this lack of diversity in the hierarchies of the industry is about building networks of trust, which can raise barriers to newcomers (Field, forthcoming b). Interlocutors are making and managing investments and loans worth billions of dollars, they tell me, and they want to work with people they know and are familiar with - implying that informal social networks are an artefact of past capital practices and the basis for new capital arrangements.

\section{Embracing and escaping precariousness: 'It's the way you live'}

Despite his stable employment for the time being amid a wave of bankruptcies since late 2019, Peter's current role is not the end of his ambition in the hydrocarbon industry. He wants to build and run his own exploration and production company. His own company would potentially enable him to be in a decisionmaking role with even greater influence and control. Peter explains: 'I'm at a stage now where I really want to do something. One more shot at: build it and run it ... be in a decision-making role... even if you're out of work.' again.

The idea of wanting to 'build' something is one I hear often from interlocutors and it reflects a desire to assert greater agential control within the industry and over one's career trajectory. In some sense, it is akin to wanting to 'own where they work' (Souleles, 2020: 30). ${ }^{7}$ It is financially risky because it could fail and, ultimately, as he says, he could be out of work again; or, it could be a success and he could make a lot of money doing it - at least he hopes so. He embraces precariousness as a means to escape precariousness. Peter approaches this potentiality with a sense of optimistic fatalism, he is well aware how precarious work can be, even for experienced experts like him. 'No one is above it', Peter says, referring to the havoc that falling oil and gas prices can wreak on companies and careers. Even the 'icons or mini icons' in the industry can fail he told me - suggesting a shared sense of precariousness. For Peter, hard times could mean forgoing a salary for months when things are 'awful'. He has enough savings to do that, but he cannot 'bet the farm', he told me, because he has family (including kids in college) who depend on him financially. Peter is not 'rich' by industry standards, but he has enough wealth to have 'options' he says, 
revealing the sort of financial privilege he enjoys and that the precariousness he embraces will not end in complete financial ruin.

His pursuit of greater power in the face of precariousness is shaped by the industry's social networks he told me, explaining:

I don't want to retire. I could tough talk like I'm going to call it quits, and my wife and I would sell our house and downsize, and still have more money than most. It's hard to work around people who've made it ... the other day we were talking about how many billionaires I've met and ones that weren't billionaires before. You meet a few of those where it's like, he's just a guy ... that twists your ending.

Having his end goals 'twisted' not only reflects the sentiments of other interlocutors I know who also wish to be 'billionaires', but also the ways in which those at the very top of the informal social hierarchies in the industry influence the personal goals of those in its upper expert ranks. Being a billionaire is an ultimate form of agential social power - it is to be recognized as having 'made it' and to be endowed with the capacity to exert philanthropic influence and control over capital. It is to escape precariousness. 'Billionaires' and places such as the Petroleum Club, where cross-sections of the industry's social elite come to mingle, serve as emblematic reminders that the US hydrocarbon industry can endow 'exceptional' individuals that are willing to face social and employment precariousness with great wealth, influence and control. These reminders invoke socio-corporeal performances among experts and help give shape to the industry's ever shifting hierarchies that define those at the top from those in the echelons below, where precariousness rises as one descends the hierarchy. In this sense, the distinction between precariousness and precarity becomes blurred; while precariousness is shared, billionaires are the exception. The degree to which it is shared, moreover, varies based on where one finds oneself in the industry's hierarchies. While interlocutors I know are not part of the precariat, these delineations are closer to what Butler (2009) describes as precarity rather than precariousness. Reflecting on the tension between pursuit of social power and the precariousness of working in the industry, Peter explains: 'It's not just money, it's the way you live.' What he suggests is that precariousness (or precarity) is a way of life for those working in the industry that it is as integral to its social structures as the wealth it generates - defining its hierarchical structures, where people fit into these structures, and how they live.

\section{Conclusion}

Sam and Peter do not see themselves as victims, but as entrepreneurs, willing to optimistically embrace the precariousness of working in the US hydrocarbon industry. ${ }^{8}$ My ethnographic encounters with Sam show how operating in spaces emblematic of wealth and maintaining social relationships within the industry's upper echelons help hedge the erosion of his social power and buffer his employment precariousness. My ethnographic encounters with Peter show how at times he 
has found himself in Sam's position and that his informal social networks helped him weather these periods of 'self-employment'. His social networks in the industry also inform his ambition of wanting to be a billionaire. These social networks that Sam and Peter share in the industry are not only a relic of past capital practices, but the basis for new capital arrangements and a barrier to those not already inducted into them. They, in part, define the industry's shifting hierarchies and are the social glue that holds the middle and upper echelons of this community together through thick and thin - through boom and bust, through employment and unemployment. In some ways these examples echo Mills' (1964 [1956]: 11, 37) argument about the importance of informal 'crowds' of old, new and aspiring upper classes who know and see each other socially and in business - forming overlapping social bonds that influence both spheres of life. Social power in these examples, I have shown, emerges as Foucauldian-like relations of power that are semi-fixed by formal and informal institutions, but perpetually negotiated and not fixed once and for all. Informal social networks are a way by which interlocutors I know can secure some of their expert social power, which can be eroded by unemployment and employment precariousness. These networks can hedge off some precariousness by helping interlocutors appear to stay 'in the game' and regain employment; both Sam and Peter credit their networks with securing various positions over their careers. Their socio-corporeal performances in exclusive industry associations and spaces, I have shown, are key to their participation in, and maintenance of, these networks.

How Sam, Peter and others negotiate social power and precariousness through these informal networks not only reveals novel insights into the hydrocarbon industry's expert hierarchies, but also how the boundary between precariousness and precarity can be obscured. Interlocutors I know have a shared sense of precariousness associated with working in the oil and gas industry, yet this precariousness is not equal. This makes this precariousness more akin to what Butler (2009) calls precarity - a concept typically reserved for the precariat and those most vulnerable in society. While the precariat might identify specific groups of people, these ethnographic examples raise the question of whether social and employment precariousness can be more broadly defined as a fundamental characteristic of capitalism that touches all but billionaires. In an industry that is largely opaque and seen as monolithically 'powerful' to outsiders, precariousness is as pervasive as the wealth that flows through it.

\section{Acknowledgements}

I wish to extend my deepest thanks to Mette High for her tireless leadership and thoughtful comments on two earlier versions of this manuscript. I wish to thank my partner Meagan Crane for her unwavering support, comments and suggestions throughout on various iterations of this article. I also extend my thanks to Daniel Souleles and Matthew Archer for organizing this special issue and the anonymous reviewers for their helpful feedback. Thanks are also due to members of the Centre for Energy Ethics research team for their critical feedback on this paper and in particular Sarah O'Brien. Many thanks are due to 
friends and interlocutors in Houston, Texas, without whom this article would not be possible. Any shortcomings are entirely my own.

\section{Declaration of conflicting interests}

The author(s) declared no potential conflicts of interest with respect to the research, authorship, and/or publication of this article.

\section{Funding}

The author(s) disclosed receipt of the following financial support for the research, authorship, and/or publication of this article: This project has received funding from the European Research Council (ERC) under the European Union's Horizon 2020 research and innovation programme, grant agreement number 715146 .

\section{ORCID iD}

Sean Field (D) https://orcid.org/0000-0003-0677-5256

\section{Notes}

1. Sam is a pseudonym. The names of all interlocutors and associations in this article are pseudonyms.

2. I joined the association in mid-2019 with the help of an interlocutor.

3. Madmen is a reference to the American television drama.

4. Salverda and Skovgaard-Smith (2018) make a similar argument in their study of FrancoMauritian management consultants.

5. I use 'control' to mean the capacity to direct and 'influence' to mean the capacity to persuade.

6. These are industry-wide statistics, but my observations coincide with these statistics.

7. Souleles' (2020) analysis focuses on Employee Stock Ownership Plan companies. While very different, both ESOPs and Peter address a desire to exert agential control over a firm.

8. These sentiments may be interpreted as self-presentation, where interlocutors wish to appear in control and satisfied with their situation but feel very differently than they appear or purport to. I cannot exclude this possibility. However, for interlocutors like Peter, who I got to know well, my sense is that these sentiments are genuine.

\section{References}

Allison A (2013) Precarious Japan. Durham, NC: Duke University Press.

Appel H (2019) The Licit Life of Capitalism: US Oil in Equatorial Guinea. Durham, NC: Duke University Press.

Appel H, Mason A and Watts M (2015) Introduction: Oil talk. In Appel H, Mason A and Watts M (eds) Subterranean Estates: Life Worlds of Oil and Gas. London: Cornell University Press, pp. 1-26

Boyer D (2008) Thinking through the Anthropology of Experts. Anthropology in Action 15(2): 38-46.

Boyer D (2014) Energopower: An introduction. Anthropological Quarterly 87(2): 309-333. Butler J (2004) Precarious Life: The Powers of Mourning and Violence. London: Verso. 
Butler J (2009) Frames of War: When Is Life Grievable? London: Verso.

Carr ES (2010) Enactments of expertise. Annual Review of Anthropology 39(1): 17-32.

Clark B (2016) Oil Capital: The History of American Oil, Wildcatters, Independents and Their Bankers. San Francisco: IngramSpark.

Courtois A (2013) Becoming elite: Exclusion, excellence, and collective identity in Ireland's top fee-paying schools. In: Abbink J and Salverda T (eds) Anthropology of Elites: Power, Culture and the Complexities of Distinction. New York: Palgrave Macmillan, pp. 163-183.

Field S (in press) Risk and responsibility: Private equity financiers and the US shale revolution. Economic Anthropology 9(1)

Field S (forthcoming a) Running the math and speaking economics: The financial lexicon and allegories of the US oil and gas sector.

Field S (forthcoming b) White oil: Responsibility and the corporeal limits of expertise in the US energy capital.

Foucault M (1994) Ethics: Subjectivity and Truth, ed. Rainbow P. New York: The New Press.

Graeber D (2001) Toward an Anthropological Theory of Value: The False Coin of Our Own Dreams. New York: Palgrave Macmillan.

Greater Houston Partnership (2020) Energy. Available at: https://www.houston.org/why-h ouston/industries/energy (accessed July 2020).

High MM (2019) Projects of devotion: Energy exploration and moral ambition in the cosmoeconomy of oil and gas in the western United States. Journal of the Royal Anthropological Institute 25(1): 29-46.

High MM (forthcoming) Utopias of oil: Energy finance and entrepreneurial ambition in the US oil and gas industry. Cultural Anthropology.

High MM and Field S (2020). Oil, oil, who wants some oil? Part 2: Pipelines and oil prices. The Energy Blog. Available at: https://energyethics.ac.uk/blog/oil-oil-who-wants-someoil-part-2-pipelines-and-oil-prices/ (accessed July 2020).

Ho K (2009) Liquidated: An Ethnography of Wall Street. London: Duke University Press.

Huber MT (2013) Lifebood: Oil, Freedom, and the Forces of Capital. Minneapolis, MN: University of Minnesota Press.

Hughes D (2017) Energy without Conscience: Oil, Climate Change, and Complicity. Durham, NC: Duke University Press.

Kasmir S (2018) Precarity. In: The Cambridge Encyclopaedia of Anthropology, ed. Stein F et al. Available at: http://doi.org/10.29164/18precarity (accessed April 2021).

Lennon M (2017) Decolonizing energy: Black Lives Matter and technoscientific expertise amid solar transitions. Energy Research and Social Science 30(1): 18-27.

Maddow R (2020) Blowout: Corrupted Democracy, Rogue State Russia, and the Richest, Most Destructive Industry on Earth. London: Random House.

Mason A (2019) Consulting virtue: From judgement to decision-making in the natural gas industry. Journal of the Royal Anthropological Institute 25(1): 124-139.

Mason A and Stoilkova M (2012) Corporeality of consultant expertise in Arctic natural gas development. Journal of Northern Studies 6(2): 83-96.

Mattingly C (2012) Two virtue ethics and the anthropology of morality. Anthropological Theory 12(2): 161-184.

McLean B (2018) Saudi America: The Truth about Fracking and How It's Changing the World. New York: Columbia Global Reports. 
Mills CW (1964 [1956]) The Power Elite. New York: Oxford University Press.

Miyazaki H (2013) Arbitraging Japan: Dreams at the End of Finance. London: University of California Press.

Osborne J (2020). Can the oil sector get work? Houston Chronicle. Available at: https:// www.houstonchronicle.com/business/energy/article/Can-the-oil-sector-get-woke15339214.php (accessed July 2020).

Salverda T and Abbink J (2013) Introduction: An anthropological perspective on elite power and the cultural politics of elites. In: Abbink $J$ and Salverda $\mathrm{T}$ (eds) Anthropology of Elites: Power, Culture and the Complexities of Distinction. New York: Palgrave Macmillan, pp. 1-28.

Salverda T and Skovgaard-Smith I (2018) Attribution and contestation: Relations between elites and other social groups. Critique of Anthropology 38(3): 265-284.

Simpson M (2019) The annihilation of time by space: Pluri-temporal strategies of capitalist circulation. ENE: Nature and Space 2(1): 110-128.

Souleles D (2020) Another workplace is possible: Learning to own and changing subjectivities in American employee-owned companies. Critique of Anthropology 40(1): 28-48.

Tsing AL (2000) Inside the economy of appearances. Public Culture 12(1): 115-144.

Weszkalnys G (2015) Geology, potentiality, speculation: On the indeterminacy of First Oil. Cultural Anthropology 30(4): 611-639.

Wood C (2016) Inside the halo zone: Geology, finance, and the corporate performance of profit in a deep tight oil formation, Economic Anthropology 3(1): 43-56.

Wood C (2019) Orphaned wells, oil assets, and debt: The competing ethics of value creation and care within petrocapitalist projects of return. Journal of the Royal Anthropological Institute 25(1): 67-90.

Yanosek K, Ahmad S and Abramson D (2019) How women can help fill the oil and gas industry's talent gap. McKinsey \& Company. Available at: https://www.mckinsey.com/ industries/oil-and-gas/our-insights/how-women-can-help-fill-the-oil-and-gas-industrystalent-gap (accessed 16 July 2021).

Zaloom C (2004) The productive life of risk. Cultural Anthropology 19(3): 365-391.

\section{Author biography}

Sean Field is a post-doctoral research fellow in the Department of Social Anthropology and the Centre for Energy Ethics at the University of St Andrews. His work explores the calculation of risk, the performance of financial expertise, and the ethical valuation of energy resources and extractive energy technologies. 